\title{
Keragaman Entomopatogenik Fungi Lokal dan Pemanfaatanya Untuk Menjaga Kualitas Sayuran Organik Brastagi
}

\author{
${ }^{(1)}$ Drs. Sularno, M.P, ${ }^{(2)}$ Drs. Edi Azwar, M.Si \\ Dosen Program Studi Pendidikan Biologi FKIP Universitas Islam Sumatera Utara ${ }^{(1)(2)}$ \\ svlarno@yahoo.co.id, ediazwar@fkip.uisu.ac.id
}

\begin{abstract}
ABSTRAK
Tujuan penelitian adalah untuk mengetahui keragaman fungi entomopatogen yang ada disekitar lahan tanaman sayuran Brastagi dan manfaatnya dalam pengendalian hama-hama yang menyerang sayuran, sehingga bisa dimanfaatkan guna menjaga kwalitas sayuran organik. Metode yang digunakan adalah eksplorasi fungi dengan umpan larva serangga Tenebrio molitor, fungi yang menginfeksi larva diisolasi dengan menggunakan media Potato dekstrosa agar (PDA), kemudian dilakukan identifikasi makroskopik terhadap fungi yang ditemukan serta mendeskripsikan manfaat fungi-fungi tersebut dalam perananya sebagai pengendalian hama terpadu secara hayati. Pada tahap lanjut fungi-fungi tersebut dapat dikembangkan untuk diaplikasikan di lapangan sehingga petani bisa mengendalikan hama sayuran tanpa penggunaan pestisida.
\end{abstract}

Kata Kunci : Inventarisasi, Tumbuhan Tingkat Tinggi, Botani Phanerogamae

\begin{abstract}
The purpose of the study was to determine the diversity of entomopathogenic fungi that exist around Brastagi vegetable crops and their benefits in controlling pests that attack vegetables, so that they can be used to maintain the quality of organic vegetables. The method used is exploration of fungi with bait of insect larvae Tenebrio molitor, fungi that infect larvae isolated using Potato dextrose agar (PDA) media, then macroscopic identification of fungi found and describing the benefits of these fungi in their role as integrated pest control biological. In the later stages these fungi can be developed to be applied in the field so that farmers can control vegetable pests without the use of pesticides.
\end{abstract}

Keywords : Inventory, Higher Level Plants, Botanical Phanerogamae

\section{PENDAHULUAN}

\section{Latar Belakang}

Pestisida digunakan secara luas dalam produksi pertanian. Pestisida berfungsi untuk mencegah atau produksi tanaman dan menjaga kwalitas produk tanaman. Meskipun regulasi penggunaan mengendalikan hama, penyakit, gulma dan pathogen tanaman lainnya sebagai upaya mengurangi kehilangan pestisida diatur dengan sangat ketat, namun perhatian terhadap dampak negative pestisida pada kesehatan manusia dari pestisida yang terpapar maupun residu pada makanan dan air minum terus diteliti dan dikembangkan. Seiring dengan meningkatanya kesadaran masyarakat akan pentingnya kesehatan dan bahayanya pestisida, maka sayuran organik bebas pestisida menjadi alternatif penting untuk menciptakan masyarakat yang sehat lewat konsumsi sayuran dan buah. Brastagi, sebagai gerbang eksport sayur dan buah sumatera utara punya potensi untuk menjadi sentra produksi sayur organik, dengan lahan seluas 25,96 ha, saat ini sedang digalakkan 
Sularno, A. Edi : Keragaman Entomopatogenik Fungi Lokal dan Pemanfaatanya untuk Menjaga Kualitas Sayuran Organik Brastagi

budidaya sayuran organik baik oleh lembaga penelitian maupun masyarakat setempat (Badan Penelitian dan Pengembangan Pertanian, 2013). Tantangan yang dihadapi para pelaku budidaya sayur organik adalah meningkatnya serangan hama dan lahan pertanian yang selama ini menggunakan pupuk sintesis. Alternatif pengendalian hama untuk sayuran organic adalah pemanfaatan musuh alami. Fungi Entomopatogen mempunyai kisaran inang yang sangat luas pada kelas insecta. Serangga hama yang dapat menjadi inang mulai dari Lepidoptera, coleopteran, diptera, orthoptera dan ordo serangga lainnya. Entomopathogenic fungi, Verticillium lecanii, Beauveria bassiana and Metarhizium anisopliaesecara intensif diteliti untuk digunakan sebagai musuh alami utama hama aphid dan hama utama pertanian lainnya (Roberts and St. Leger, 2004). Beauveria bassiana (Bals.)Vuill.Telah dikembangkan sebagai insectisida mikrobial untuk membasmi banyak hama utama, termasuk lepidopterans and orthopterans. sekitar $33.9 \%$ dari mycoinsecticidadibuat dari B. bassiana, diikuti oleh Metarhizium anisopliae (33.9\%), Isaria fumosorosea $(5.8 \%$ ) and Beauveria brongniartii $(4.1 \%)$ (Wraight and Carruthers, 1999). Oleh karena itu keberadaan fungi-fungi tersebut sangat besar peranannya dalam mengatasi hama sayuran di Brastagi sebagai sentra sayuran oranik di Sumatera Utara.

\section{Perumusan Masalah}

Diantara musuh alami pengendali hama adalah fungi pathogen pada serangga. Secara umum fungi pathogen pada serangga diantaranya adalah Metarhizium anisopliae, Beauveria bassiana, Nomuraea rileyi, Paecilomyces farinosus and Paecilomyces fumosoroseus(Takhur dan Sandhu, 2010), Lagenidium, Coelomomyces, Conidiobolus, Entomophaga, Entomophthora, Erynia, Neozygites, Pandora, Zoophthora, Cordyceps, Hypocrella, Torrubiella, Aschersonia, Hirsutella, Tolypocladium,dan Verticillium (Pell dan Shah, 2003). Eksplorasi, budidaya dan pemanfaatan fungi pathogen tersebut belum banyak dilakukan. Oleh karena itu perlu adanya penelitian intensif untuk eksplorasi dan mengetahui keragaman fungi pathogen pengendali hama yang ada di Brastagi dan pemanfaatanya dalam peningkatan kwalitas sayuran organik.

\section{Tujuan Penelitian}

Tujuan penelitian adalah untuk mengetahui keragaman fungi entomopatogen yang ada disekitar lahan tanaman sayuran Brastagi dan manfaatnya dalam pengendalian hama-hama yang menyerang sayuran, sehingga bisa dimanfaatkan guna menjaga kwalitas sayuran organik

\section{Manfaat Penelitian}

Fungi Entomopatogen mempunyai kisaran inang yang sangat luas pada kelas insecta. Serangga hama yang dapat menjadi inang mulai dari Lepidoptera, coleopteran, diptera, orthoptera dan ordo serangga lainnya. Entomopathogenic fungi, Verticillium lecanii, Beauveria bassiana and Metarhizium anisopliaesecara intensif diteliti untuk digunakan sebagai musuh alami utama hama aphid dan hama utama pertanian lainnya (Roberts and St. Leger, 2004). Beauveria bassiana (Bals.)Vuill.Telah dikembangkan sebagai insectisida mikrobial untuk membasmi banyak hama utama, termasuk lepidopterans and orthopterans. sekitar 33.9\% dari mycoinsecticidadibuat dari B. bassiana, diikuti olehMetarhizium anisopliae (33.9\%), Isaria fumosorosea (5.8\%) and Beauveria brongniartii (4.1\%) ( Wraightand Carruthers, 1999). Oleh karena itu keberadaan fungi-fungi tersebut sangat besar peranannya dalam mengatasi hama sayuran di Brastagi sebagai sentra sayuran oranik di Sumatera Utara.

\section{METODE PENELITIAN}


Sularno, A. Edi : Keragaman Entomopatogenik Fungi Lokal dan Pemanfaatanya untuk Menjaga Kualitas Sayuran Organik Brastagi

Penelitian ini menggunakan metode eksplorasi dengan umpan larva Tenebrio molitor, bertujuan untuk mengetahui keragaman fungi entomopatogen yang ada di lahan tananaman sayuran di Brastagi. Tahap Pertama penelitian melakukan eksplorasi fungi yang ada di tanah sekitar akar tanaman dengan kedalaman 5 sampai $15 \mathrm{~cm}$. Sampel tanah diambil sesuai dengan penetapan sampling. Tanah kemudian dimasukkan kedalam plastikdan dicampur hingga homogen. Sampel tanah yang didapatkan diletakkan ke dalam wadah plastik, diisi kira-kira setengah dari volume wadah. Sebelum larva Tenebrio molitor dimasukkan, tanah di dalam wadah dilembabkan dengan menambahkan air secukupnya. Meletakkan larva Tenebrio molitor di permukaan tanah dalam wadah, larva yang dimasukkan adalah larva yang baru molting (ganti kulit) yaitu yang berwarna putih Selanjutnya wadah ditutup menggunakan kain kasa agar larva tidak keluar dari wadah, kemudian diinkubasikan selama 1 sampai 2 minggu di tempat gelap agar larva perangkap bergerak aktif, sehingga mudah kontak dengan fungi entomopatogen yang berada di dalam sampel tanah tersebut. LarvaTenebrio molitor yang terinfeksi fungi diisolasi dengan cara menanamkan sampel jaringan terinfeksi pada media Potato Dekstrose Agar (PDA) dan diinkubasikan selama 5 sampai 7 hari. Isolasi dilakukan dengan cara mencelupkan sampel jaringan terinfeksi (larva Tenebrio molitor) beberapa saat $( \pm 3$ menit) ke dalam larutan clorox, alkohol, kemudian dibilas dengan aquadest steril. Fungi yang tumbuh pada media diidentifikasi dan ditularkan kembali (reinokulasi) pada serangga uji. Fungi entomopatogen yang virulen diperbanyak dan dikembangkan untuk pengendalian di lapangan.

\section{HASIL DAN PEMBAHASAN}

Eksplorasi fungi yang ada ditanah sekitar akar tanaman dengan kedalaman 5 sampai 15 $\mathrm{cm}$. Sampel tanah diambil dari sentra perkebunan tanaman holtikultura yang didominasi tanaman kol/kubis . Lokasi Pengambilan sampel tanah di desa Gajah, Kecamatan Simpang Empat Kabupaten Tanah Karo Sumatera Utara. Sampel tanah diambil dari lahan tanaman kubis, sawi, brokoli, buncis dan tomat. Masing-masing lahan diambil 7 sampel tanah secara diagonal.

Sularno, A. Edi : Keragaman Entomopatogenik Fungi Lokal dan Pemanfaatanya untuk Menjaga Kualitas Sayuran Organik Brastagi

Sampel tanah yang didapatkan diletakkan ke dalam wadah plastik, diisi kira-kira setengah dari volume wadah. Sebelum larva Tenebrio molitor dimasukkan, tanah di dalam wadah dilembabkan dengan menambahkan air secukupnya. Meletakkan larva Tenebrio molitor di permukaan tanah dalam wadah, larva yang dimasukkan adalah larva yang baru molting (ganti kulit) yaitu yang berwarna putih Selanjutnya wadah ditutup menggunakan kain kasa agar larva tidak keluar dari wadah, kemudian diinkubasikan selama 1 sampai 2 minggu di tempat gelap agar larva perangkap bergerak aktif, sehingga mudah kontak dengan fungi entomopatogen yang berada di dalam sampel tanah tersebut. Hasil eksplorasi fungi dari masing-masing dapat dilihat pada table berikut :

Tabel Jenis lahan tanaman sayuran dan larva Tenebrio molitor yang terinfeksi fungi

\begin{tabular}{|c|c|c|c|c|}
\hline No & $\begin{array}{l}\text { Tanah dari lahan } \\
\text { tanaman }\end{array}$ & $\begin{array}{l}\text { Kondisi Larva } \\
\text { Tenebrio } \\
\text { molitor }\end{array}$ & Jenis Fungi & Frekwensi \\
\hline \multirow[t]{2}{*}{1} & \multirow[t]{2}{*}{ kubis } & \multirow[t]{2}{*}{\begin{tabular}{|l|} 
terinfeksi \\
\end{tabular}} & Beuveria bassiana & 2 \\
\hline & & & $\begin{array}{l}\text { Metarhizium } \\
\text { anisopliae }\end{array}$ & 1 \\
\hline \multirow[t]{3}{*}{2} & \multirow[t]{3}{*}{ Sawi putih } & \multirow[t]{3}{*}{ terinfeksi } & Beuveria bassiana & 2 \\
\hline & & & $\begin{array}{l}\text { Metarhizium } \\
\text { anisopliae }\end{array}$ & 8 \\
\hline & & & & 1 \\
\hline \multirow[t]{2}{*}{3} & \multirow[t]{2}{*}{ Bunga kol } & \multirow[t]{2}{*}{ terinfeksi } & Beuveria bassiana & 1 \\
\hline & & & $\begin{array}{l}\text { Metarhizium } \\
\text { anisopliae }\end{array}$ & 5 \\
\hline \multirow[t]{2}{*}{4} & \multirow[t]{2}{*}{ Buncis } & \multirow[t]{2}{*}{ terinfeksi } & Beuveria bassiana & 1 \\
\hline & & & $\begin{array}{l}\text { Metarhizium } \\
\text { anisopliae }\end{array}$ & 3 \\
\hline \multirow[t]{2}{*}{5} & \multirow[t]{2}{*}{ Tomat/cabai } & \multirow[t]{2}{*}{ Tidak terinfeksi } & - & - \\
\hline & & & - & - \\
\hline
\end{tabular}

Dari tabel terlihat bahwa hamper semua sumber tanah mengandung fungi entomopatogenik fungi dan dari lahan sawi putih yang paling banyak frekwensi terinfeksi. Sedang tanah dari tomat dan cabai tidak ada larva yang terinfeksi. Sebagai informasi tanah yang diambil dari kebun kubis, sawi putih, bunga kol dan buncis adalah kebun yang tidak lagi dirawat dan diperlakukan dengan pestisida karena merupakan lahan pasca panen. Sehingga jumlah serangga cukup banyak terdapat dilahan. Sedang tanah dari tanaman tomat/ cabai merupakan kebun yang masih aktif dirawat karena dalam fase pertumbuhan dan memasuki fase reproduktif atau munculnya bunga dan buah. Kebun yang masih intensif dirawat dengan perlakuan penyemprotan pestisida. Intensitas penyemprotan pestisida dalam satu minggu sebanyak 3 sampai 4 kali. Tahap Isolasi LarvaTenebrio molitor yang terinfeksi fungi diisolasi dengan cara menanamkan sampel jaringan terinfeksi pada media Potato Dekstrose Agar (PDA) dan diinkubasikan selama 5 sampai 7 hari. Isolasi dilakukan dengan cara mencelupkan sampel jaringan terinfeksi (larva Tenebrio molitor) beberapa saat ( \pm 3 menit) ke dalam larutan clorox, alkohol, kemudian dibilas dengan aquadest steril. Dikeringkan dengan tissue steril dan diletakkan di atas kertas saring lembab steril. Konidia fungi entomopatogenik yang keluar dari tubuh larva dibiakkan pada medium PDA menggunakan jarum ose. 
Sularno, A. Edi : Keragaman Entomopatogenik Fungi Lokal dan Pemanfaatanya untuk Menjaga Kualitas Sayuran Organik Brastagi

\section{DAFTAR PUSTAKA}

Badan Penelitian dan Pengembangan Pertanian. 2013. Jakarta Litbang Pertanian.htm email: info@ litbang.deptan.go.id

Bale,J.S; J.C. Van Lenteren; and F. Bigler. 2008. Biological Control and sustainable food Production. Philos. Trans.R.Soc.Lond. B. Biol.Sci.

Blomquist G.J., and Vogt R.G., 2003, Biosynthesis and detection of pheromones and plant volatiles - introduction and overview, In: Blomquist G.J., and Vogt R.G. (eds.), Insect Pheromone Biochemistry and Molecular Biology, Elsevier Academic Press, London, pp.137-200

Damalas, Christos A and Ilias G. Eleftherohorinos 2011. Pesticide Exposure, Safety Issues, and Risk Assessment IndicatorsInt J Environ Res Public Health. 2011 May; 8(5): 1402-1419.

Khan, Sehroon et al. 2012. Entomopathogenic Fungi as Microbial Biocontrol Agen.Molecular Plant Breeding, 2012, Vol. 3, No. 7

Pell, J.K and Shah, P.A. 2003. Entomopathogenic fungi as biological control agents. Appl Microbial Biotechnol (2003) 